\title{
Correction to 'Genotyping of Malaysian G6PD-deficient neonates by reverse dot blot flow-through hybridisation'
}

\author{
M. F. Alina - R. Z. Azma • J. Norunaluwar • I. Azlin • A. J. Darnina • F. C. Cheah • A. R. Noor-Farisah • A. A. Siti-Hawa • \\ X. R. K. Danny • Noor-Fadzilah Zulkifli • O. Ainoon
}

Published online: 8 May 2020

(c) The Author(s), under exclusive licence to The Japan Society of Human Genetics 2020

Correction to: Journal of Human Genetics

https://doi.org/10.1038/s10038-019-0700-7

The authors regret to inform that the incorrect image was used in Fig. 2 (Electropherogram showing results of DNA sequencing of the two novel mutations. (A) G6PD nt $1361 \mathrm{G}>\mathrm{T}$, (B) G6PD nt 1030G $>$ A) in the original version of the manuscript. The corrected Fig. 2 is shown below. The caption remains the same.
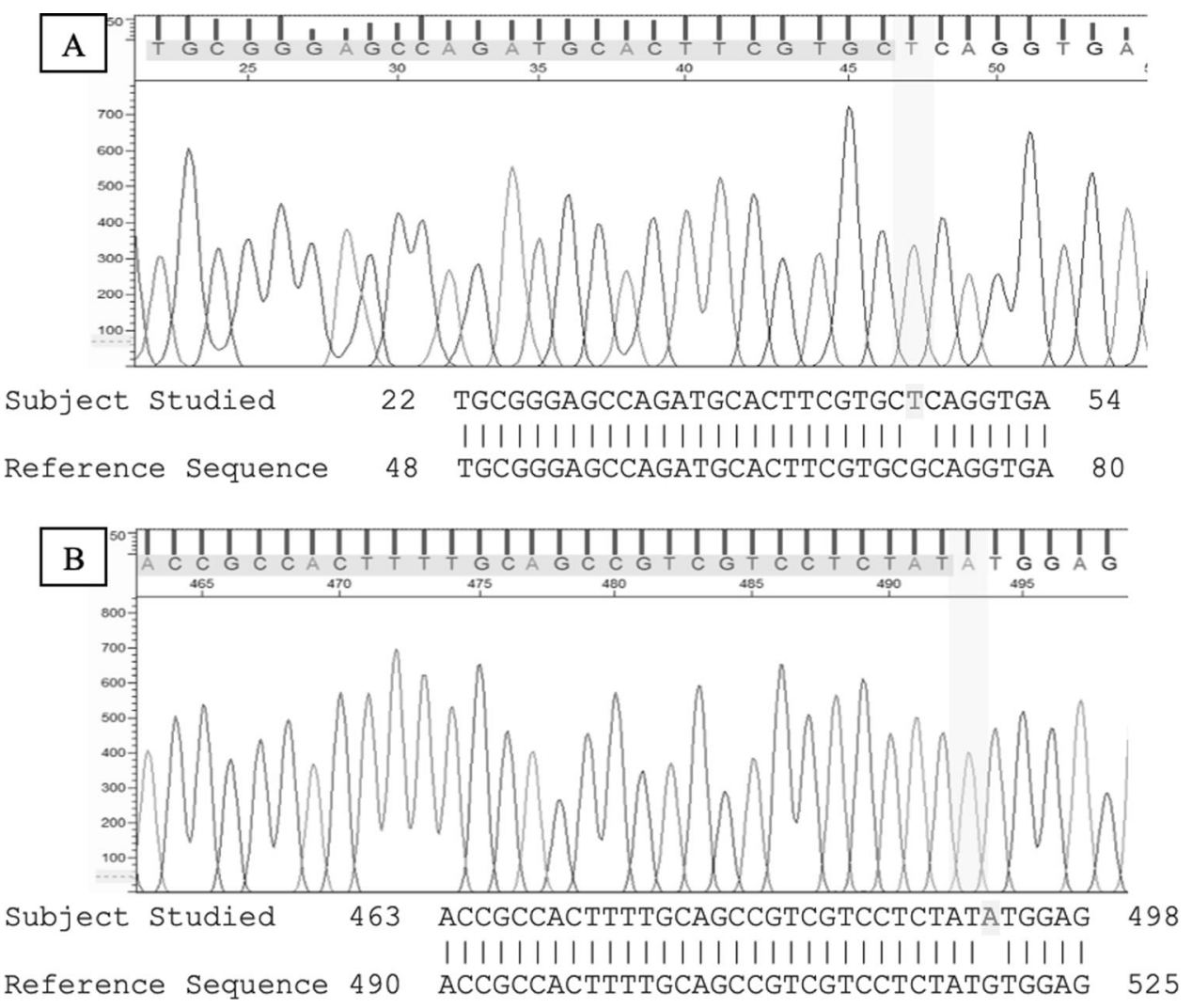

Fig. 2 Electropherogram showing results of DNA sequencing of the two novel mutations. (A) G6PD nt 1361G>T, (B) G6PD nt 1030G>A. 